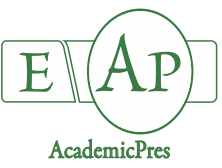

Reis LC et al. (2020)

Notulae Botanicae Horti Agrobotanici Cluj-Napoca 48(1):210-220

DOI: $10.15835 /$ nbha48111757

Research Article

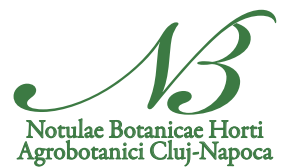

\title{
Chlorophyll $a$ fluorescence as an indicator of water stress in Calophyllum brasiliense
}

\author{
Lucas C. REIS ${ }^{1}$, Silvana P.Q. SCALON ${ }^{1 *}$, Daiane M. DRESCH ${ }^{1}$, \\ Andressa Caroline FORESTI ${ }^{1}$, Cleberton C. SANTOS ${ }^{1}$, \\ Zefa V. PEREIRA ${ }^{2}$
}
${ }^{I}$ Federal University of Grande Dourados, Faculty of Agricultural Sciences, Road Dourados-Itahum, Km 12, Rural Subdivision, CEP: 79804970,Dourados,State Mato Grossodo Sul, Brazil; lucasc_reis@hotmail.com;daiamugnol@hotmail.com; andressaforesti13@hotmail.com; cleber_frs@yahoo.com.br; silvanascalon@ufgd.edu.br (*correspondingauthor)
${ }^{2}$ Federal University of Grande Dourados, Faculty of Biological and Environmental Sciences, Road Dourados-Itahum, Km 12, Rural Subdivision, CEP: 79804970,Dourados, State Mato Grosso do Sul, Brazil; zefapereira@ufgd.edu.br

\begin{abstract}
The objective of this study was to evaluate chlorophyll $a$ fluorescence as a stress indicator in Calophyllum brasiliense Cambess seedlings grown with different concentrations of abscisic acid (ABA) under intermittent water deficit condition: daily irrigation without $\mathrm{ABA}$ (I); daily irrigation + $10 \mu \mathrm{M}$ ABA (I 10); daily irrigation $+100 \mu \mathrm{M}$ ABA (I 100); suspension of daily irrigation without ABA (SI); suspension of daily irrigation +10 $\mu \mathrm{M} \mathrm{ABA}$ (SI 10) and suspension of daily irrigation $+100 \mu \mathrm{M}$ ABA (SI 100). The intermittent water deficit reduces water status and impairs the photochemical apparatus functioning and seedling quality. The fluorescence measurements helped identify the stress condition of water deficit in the cultivation of $C$. brasiliense and the beneficial effect of the application of $10 \mu \mathrm{M}$ of ABA in minimizing stress and facilitating the recovery of seedlings after re-irrigation, while maintaining the integrity and function of the photosynthetic apparatus.

Keywords: abscisic acid; Dickson quality; leaf area; photosystem II

Abbreviations: ABA: Abscisic acid; ChlF-a: chlorophyll a fluorescence; DQI: Dickson Quality Index; END: end of the experiment; $F_{v} / F_{m}$ : potential quantum efficiency of photosystem II; $F_{v} / F_{0:}$ efficiency of the effective photosystem in the conversion of absorbed energy; $\mathrm{F}_{0} / \mathrm{F}_{\mathrm{m}}$ : basal quantum production of nonphotochemical processes in PSII; H: height; I: irrigation; IRGA: infrared gas analyzer; P0: Photosynthesis next zero; PS II: photosystem II; RDM: root dry mass; REC: recovery; SD: stem base diameter; SI: suspention of daily irrigation; SDM: shoot dry mass; TDM: total dry mass; T0: time zero - start; WRC: water relative content
\end{abstract}

\section{Introduction}

Calophyllum brasiliense Cambess. (Clusiaceae), commonly known as 'guanandi', is a tree species native to Central and South America. In Brazil, it is found in several states, especially in the Amazon region and in the 
Cerrado, occurring spontaneously in alluvial soils with poor drainage, periodically flooded humid places, sandy to loamy soils, and acidic soils ( $\mathrm{pH}$ 4.5-6.0). It has ornamental, apicultural, and medicinal applications, and also has potential application in recovery of degraded areas, thus, facilitating the establishment of other species. Its wood is used in the construction of furniture, frames, and ships among other applications (Carvalho, 2003; Kalil Filho et al., 2007).

Although there are some reports on the water and light requirements of this species, no information is available on its potential to tolerate water deficit when induced by abscisic acid (ABA).This information is important to extend its use economically and ecologically, especially in the recovery of degraded areas subject to seasonal periods of water deficit.

Depending on climatic conditions, plants undergo physiological, anatomical, and/or structural changes to adapt and acclimate to abiotic stresses. Responses to water deficit might include leaf area reduction, leaf abscission, stomatal closure, root growth, chlorophyll reduction, photosynthesis limitation, and seedling quality reduction among other responses (Scalon et al., 2011; Asharaf and Harris, 2013; Rosa et al., 2017; Nunes et al., 2017; Vieira et al., 2017; França et al., 2017; Campelo - unpublished data).

The water deficit can change the organelle, pigment concentration and metabolites, as well as stomatal regulation (Mohammadi et al., 2015). The closing of stomatal is considered a primary mechanism to regulate the water content when the plant is under dry conditions (Kowitcharoen et al., 2015; Zhao et al., 2015).

Studies suggest that stomatal closure under water deficit can occur under the influence of the water content of the soil and/or due to the hormonal levels of the plant (Damour et al., 2010; Brodribb and McAdam, 2013). Thus, the exogenous application of some phytohormones like the ABA, you can enable the plant to adapt to hydric deficit, to mediate adaptive responses, stimulating the biosynthesis of proline and the translocation of photo assimilation (Sarafraz et al., 2014).

The chlorophyll $a$ fluorescence (ChlF-a) parameters can be used to understand the processes of tolerance and/or physiological plasticity to different water conditions (Kalaji et al., 2018), since, as the only photochemical functions reflect a reduction in the efficiency of plants to capture, transfer, and convert energy (Nesterenko et al., 2019) and the preservation of integrity or photo inhibitory damage in the reaction centers of PS II due to some stress factor.

Considering the natural habitat of this species, we hypothesized that their seedlings are sensitive to water deficit, which can be minimized by the application of ABA, and that ChlF- $a$ can indicate stress condition, which reflects on the quality of the seedling. Therefore, the aim of the present study was to evaluate ChlF- $a$ as a stress indicator in C. brasiliense seedlings grown with different concentrations of ABA and under intermittent water deficit condition.

\section{Materials and Methods}

\section{Plant and cultivation material}

The experiment was carried out in a protected environment where the seedlings of $C$. brasiliense Cambess were maintained under $30 \%$ shade and protected from rainfall using plastic cover. Seven-month old seedlings (after emergence), of mean height $14.32 \mathrm{~cm}$ and with 9.33 leaves, were grown in $7 \mathrm{~L}$ pots. All the pots were irrigated at $70 \%$ water retention capacity (WRC) of the substrate until the characterization of the seedlings at time zero, with two seedlings per pot.

The treatments included suspension of daily irrigation without the addition of $A B A$ (SI $0 A B A$ ), suspension of daily irrigation $+10 \mu \mathrm{M} \mathrm{ABA}$ (SI $10 \mathrm{ABA})$, suspension of daily irrigation $+\mathrm{ABA} 100 \mu \mathrm{M}$ (SI $100 \mathrm{ABA}$ ), daily irrigation without $\mathrm{ABA}$ (I $0 \mathrm{ABA}$ ), daily irrigation + $10 \mu \mathrm{M} \mathrm{ABA}$ (I $10 \mathrm{ABA}$ ), and daily irrigation $+100 \mu \mathrm{M} \mathrm{ABA}$ (I $100 \mathrm{ABA}$ ). Each treatment consisted of 22 pots, in addition to the six separate seedlings used for evaluation at time zero. 
For the irrigation treatments, the seedlings were divided into two groups. The first group was irrigated daily throughout the experimental period and the soil was maintained at 70\% WRC; this group was considered control based on the concentration of ABA. The second group was subjected to water deficit until the photosynthetic rate approached zero, considered the first zero photosynthesis $\left(1^{\text {st }} \mathrm{P} 0\right)$.

From the $1^{\text {st }} \mathrm{P0}$ period, all the pots were irrigated daily, and the plants were maintained at $70 \%$ WRC until recovery (REC), which was considered the stage when the seedlings under water deficit presented photosynthesis rates similar to those of irrigated seedlings (data not shown). After REC, another cycle of irrigation suspension was performed, and the seedlings were evaluated until the photosynthetic rate approached zero again, considered the second photosynthesis zero $\left(2^{\text {nd }} \mathrm{P} 0\right)$. To determine the $1^{\text {st }} \mathrm{P} 0$ and $2^{\text {nd }} \mathrm{P} 0$, photosynthesis was monitored every two days using portable LCIPro-SD (IRGA - Ifra Red Gas Analyzer) (ADC BioScientific Ltd model), considering favorable climatic conditions. Subsequently, the pots were irrigated again until REC, according to the previously established standard and final evaluation that occurred 165 days after the start of the experiment (END).

On day 17 , based on the photosynthetic rate of approximately $2 \mu \mathrm{molm}^{-2} \mathrm{~s}^{-1}$, according to pre-tests, ABA was applied at the predetermined concentrations. The results were evaluated at five periods: T0, time zero (beginning of experiment); ${ }^{\text {st }} \mathrm{P} 0$, first photosynthesis zero (day 23); $2^{\text {nd }} \mathrm{P} 0$, second photosynthesis zero (day 82); REC, recovery (day 120); and END, final evaluation (day 165). The following parameters were evaluated:

\section{Evaluations}

Chlorophyll a fluorescence: Using a portable fluorometer (OS-30p;Opti-Sciences Chlorophyll Fluorometer, Hudson, NY, USA), we determined the potential quantum efficiency of photosystem II (PS II) $\left(\mathrm{F}_{\mathrm{v}} / \mathrm{F}_{\mathrm{m}}\right)$, efficiency of the effective photosystem in the conversion of absorbed energy $\left(\mathrm{F}_{\mathrm{v}} / \mathrm{F}_{0}\right)$, and basal quantum production of non-photochemical processes in PSII $\left(\mathrm{F}_{0} / \mathrm{F}_{\mathrm{m}}\right)$. Fluorescence was determined between 8:00 and 11:00 AM was the second pair of fully expanded leaves. To determine their fluorescence, the leaves were subjected to a $30 \mathrm{~min}$ period of dark adaptation using adaptive clips, to ensure that all the reaction centers in this leaf region were open, that is, complete oxidation of the photosynthetic system of electron transport.

Relative water content (RWC): The relative water content in the leaves was determined using four leaves of each treatment, using the formula: RWC $=100 \times$ (fresh mass-dry mass/saturated mass - dry mass). The leaves were collected between 7:00 and 10:00 AM and cut into discs of known area. After weighing the fresh mass, they were placed in Petri dishes with distilled water for $24 \mathrm{~h}$ for saturation. After weighing the saturated discs, they were dried for determine the dry mass.

Chlorophyll index and leaf area: The chlorophyll index was determined using achlorophyll meter (SPAD 502; MINOLTA) (8:00 and 11:00 AM), and leaf area was determined using a leaf area integrator (Li 3100, Area Meter).

Dickson Quality Index (DQI): was calculated using the following equation DQI = TDM/ [(H/SD) + $(\mathrm{SDM} / \mathrm{RDM})]$, where TDM = total dry mass $(\mathrm{g}) ; \mathrm{SDM}=$ shoot dry mass $(\mathrm{g}) ; \mathrm{RDM}=$ root dry mass $(\mathrm{g}), \mathrm{H}=$ height $(\mathrm{cm})$ and $\mathrm{SD}=$ stem base diameter $(\mathrm{mm})$ (Dickson 1960).

\section{Experimental design and statistical analysis}

The data were evaluated in a completely randomized design with subdivided plots, where the plots represented the form of irrigation (daily irrigation - I and irrigation suspension - SI); each subplot included the three concentrations of $\mathrm{ABA}(0,10$, and $100 \mu \mathrm{M} \mathrm{ABA})$; and the sub-sub-plot included the five evaluation periods (T0, $1^{\text {st }} \mathrm{P} 0,2^{\text {nd }} \mathrm{P} 0, \mathrm{REC}$, and END). The results were subjected to the analysis of variance (ANOVA), and when significant effect was observed according to the $\mathrm{F}$ test, the means of the plots were subjected to the $t$ test of Bonferroni $(\mathrm{p} \leq 0.05)$ and the averages of subplots and sub-subplots were subjected to Tukey test $(\mathrm{p} \leq 0.05)$, using the SISVAR statistical program (Ferreira, 2014).

\section{Results}


The $F_{v} / F_{m}$ was lower in the seedlings under water deficit at the $1^{\text {st }} P 0$ period in relation to that of the irrigated seedlings (Figure 1A). The non-irrigated seedlings treated with $10 \mu \mathrm{M} \mathrm{ABA}$ presented a higher $\mathrm{F}_{\mathrm{v}} / \mathrm{F}_{\mathrm{m}}$ (0.797) than that of the seedlings subjected to other treatments, including SI 0 ABA (0.768) and SI $100 \mu \mathrm{M}$ $\mathrm{ABA}$ (0.738), and was close to that of the control I $10 \mu \mathrm{M} \mathrm{ABA}$ treatment (0.801) (Figure 1B). The seedlings subjected to the $S I 100 \mu \mathrm{M} \mathrm{ABA}$ treatments presented the lowest $\mathrm{F}_{\mathrm{v}} / \mathrm{F}_{\mathrm{m}}$ values, especially at the $1^{\text {st }} \mathrm{P} 0$ period, with an average of $<0.75$.

(A)

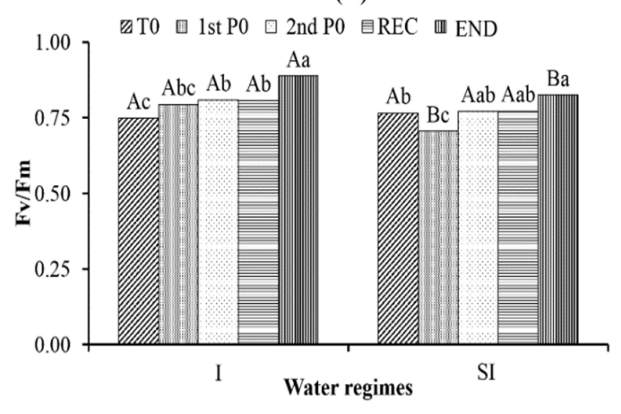

(B)

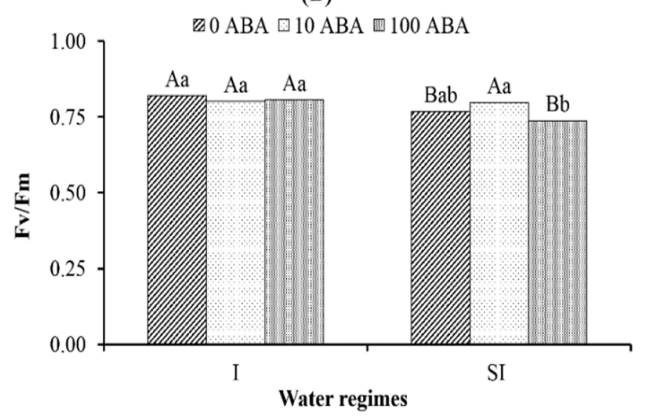

(C)

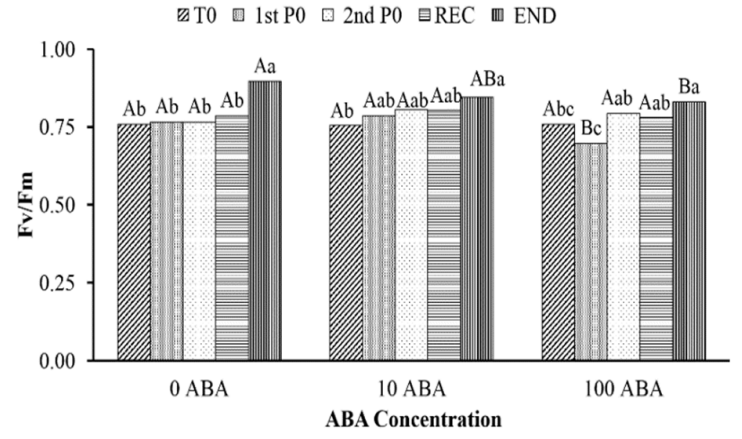

Figure 1. Quantum efficiency of photosynthetic II $\left(\mathrm{F}_{\mathrm{v}} / \mathrm{F}_{\mathrm{m}}\right)(\mathrm{A}, \mathrm{B}$, and $\mathrm{C})$ seedlings of Calophyllum brasiliense subjected to different water regimes (irrigated-I and suspension of irrigation-SI), ABA concentrations $(0,10$ and $100 \mu \mathrm{M})$ and evaluation periods (time zero-T0, first and second photosynthesis near zero - $1^{\text {st }} \mathrm{P} 0$ and $2^{\text {nd }} \mathrm{P} 0$, recovery-REC and final evaluation END).Lowercase letters compare different periods of evaluation $(A)$ and doses of $A B A(B)$ in the same water regime $(A, B)$ and different periods of evaluation in the sameABA concentration (C). Capital letters compare the same evaluation periods (A) and concentration of $\mathrm{ABA}(\mathrm{B})$ in different water regimes $(\mathrm{A}, \mathrm{B})$ and the same evaluation periods in different concentration of $\mathrm{ABA}(\mathrm{C})$

In the END evaluation, this ratio tended to increase in the seedlings of all ABA treatments, with 0.785 , 0.845 , and 0.781 , and reached a maximum of $0.896,0.845$ and 0.830 , respectively. Furthermore, the $F_{v} / F_{m}$ values of seedlings without $\mathrm{ABA}$ application varied significantly only at the END evaluation period (Figure 1C). Stressed seedlings recovered to the values close to those of the control plants when treated with $10 \mu \mathrm{M}$ $\mathrm{ABA}$. The $\mathrm{F}_{\mathrm{v}} / \mathrm{F}_{0}$ was higher at $\mathrm{T} 0(4.47)$ that at the $1^{\text {st }}$ and $2^{\text {nd }} \mathrm{P} 0$ ( 3.76 and 4.02 , respectively) (Figure $\left.2 \mathrm{~A}\right)$. The $\mathrm{F}_{\mathrm{v}} / \mathrm{F}_{0}$ value of seedlings subjected to the SI $0 \mathrm{ABA}$ treatment was lower (3.75) than that of the seedlings subjected tothe I $0 \mathrm{ABA}$ control (4.65) (Figure 2B). Stressed seedlings recovered only after re-irrigation at the end of evaluation and when treated with $\mathrm{ABA}$. 
(A)

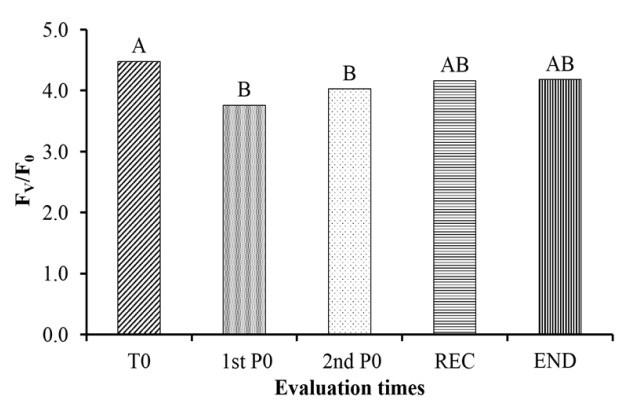

(C)

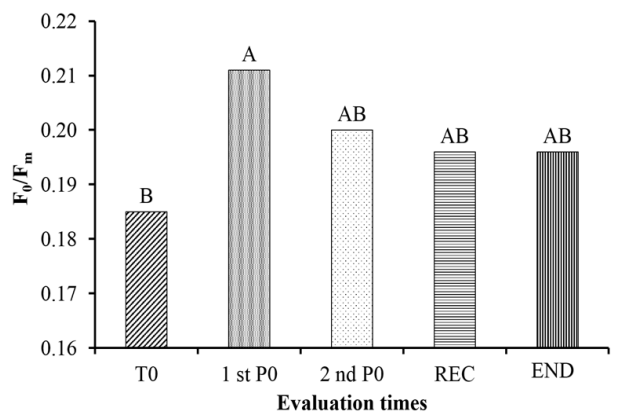

(B)

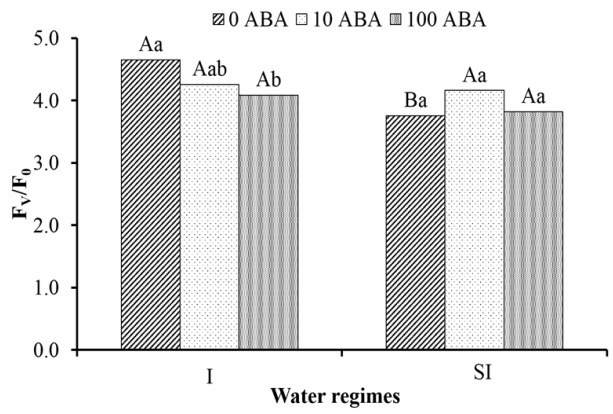

(D)

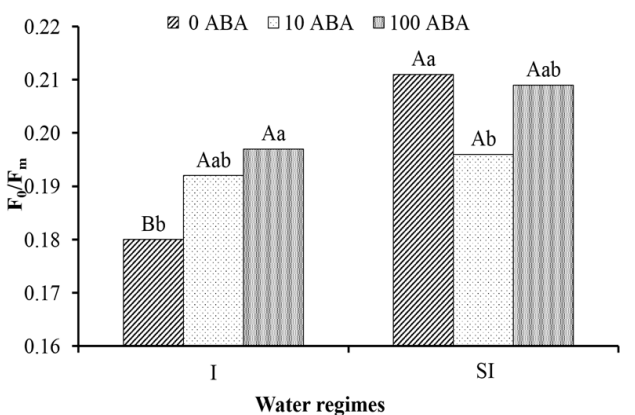

Figure 2. Efficiency of the effective photosystem in the conversion of absorbed energy $\left(F_{v} / F_{0}\right)(A, B)$ and basal quantum production of non-photochemical processes in PSII $\left(\mathrm{F}_{0} / \mathrm{F}_{\mathrm{m}}\right)(\mathrm{C}, \mathrm{D})$ seedlings of Calophyllum brasiliense subjected to different water regimes (irrigated-I and suspension of irrigation-SI), ABA concentrations $(0,10$ and $100 \mu \mathrm{M})$ and evaluation times (time zero-T0, first and second photosynthesis near zero $-1^{\text {st }} \mathrm{P} 0$ and $2^{\text {nd }} \mathrm{P} 0$, recovery-REC and final evaluation END).Capital letters comparing the same dose of $\mathrm{ABA}$ in different water regimes $(\mathrm{B}, \mathrm{D})$. Lowercase letters compared different doses of the same $\mathrm{ABA}$ water regime $(\mathrm{B}, \mathrm{D})$.

The $\mathrm{F}_{0} / \mathrm{F}_{\mathrm{m}}$ was higher at the $1^{\text {st }} \mathrm{P} 0$ period, but not significantly different from that at the $2^{\text {nd }} \mathrm{P} 0, \mathrm{REC}$, and END periods (Figure $2 \mathrm{C}$ ). The seedlings subjected to the SI 0 ABA treatment presented the $\mathrm{F}_{0} / \mathrm{F}_{\mathrm{m}}$ value (0.016) higher than that of the seedlings subjected to the SI10 ABA treatments (0.195), which reached values close to that of the seedlings subjected the I 0 ABA control treatment (0.192 higher) (Figure 2D). We also observed that the $\mathrm{F}_{0} / \mathrm{F}_{\mathrm{m}}$ values of the seedlings subjected to the SI $0 \mathrm{ABA}$ treatment was 0.031 -times higher than those of the seedlings subjected to the I 0 ABA treatment. Stressed plants recovered to values close to that of control seedling after re-irrigation when treated with $\mathrm{ABA}$.

The RWC of the leaves decreased in the seedlings under water deficit with the lowest values in the seedlings subjected to the SI without ABA and SI $100 \mu \mathrm{M}$ ABA treatments; however, the seedlings subjected to the $10 \mu \mathrm{M}$ ABA treatment presented values similar to those of the control (Figure 3A). There was a significant reduction in RWC at both $1^{\text {st }}$ and $2^{\text {nd }} \mathrm{P} 0$ periods in the seedlings grown under water deficit with elevation after re-irrigation, although it did not reach the values close to those of control seedlings (Figure 3B).

The leaf area of seedlings subjected to the $10 \mu \mathrm{M} \mathrm{ABA}$ treatment and those subjected to irrigation treatments increased and was maintained relatively high throughout the experiment (Figures $3 \mathrm{C}, \mathrm{D})$. The highest leaf area was observed in the END evaluation, and the irrigated seedlings (I) presented $105.35 \mathrm{~cm}^{2}$ more area than that of the stressed seedlings (SI). Stressed seedlings did not recover the leaf area after re-irrigation, presenting significantly lower values than that of the control plants.

The non-irrigated seedlings without ABA application presented relatively low chlorophyll index, which was low even at the $1^{\text {st }} \mathrm{P} 0,2^{\text {nd }} \mathrm{P} 0$, and REC periods, although the index increased, it did not reach the values to 
that of the control seedlings. The application of $A B A$ favored the maintenance of relatively high chlorophyll index when cultivated under water stress (Figures $4 \mathrm{~A}, \mathrm{~B}, \mathrm{C}$ ).

The lowest chlorophyll index was observed at the $1^{\text {st }} \mathrm{P} 0$ evaluation period in all the treatments with or without $\mathrm{ABA}$ application, especially in the stressed seedlings, which was $44.51 \%$ lower than that in the irrigated seedlings (Figures 4B, C).

Dickson Quality Index (DQI) increased during the experiment under both irrigation conditions. In the irrigated treatments, the values were higher than the stressed seedlings with significant differences at $2^{\text {nd }} \mathrm{P} 0$, REC, and END evaluation periods. However, stressed seedlings even after rehydration did not attain values close to those of the control seedlings (Figure 4D), suggesting that the period might not have been enough for the seedlings to recover.

(A)

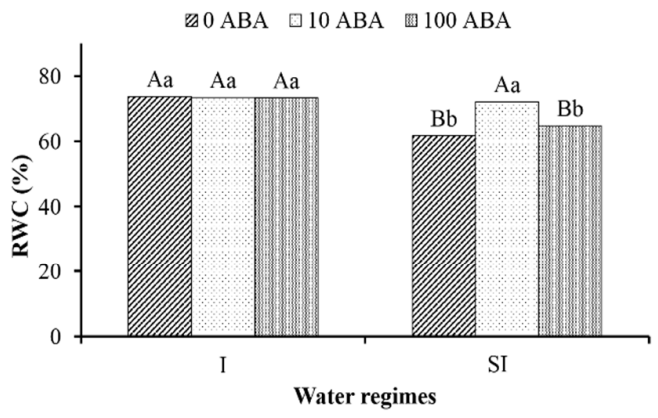

(C)

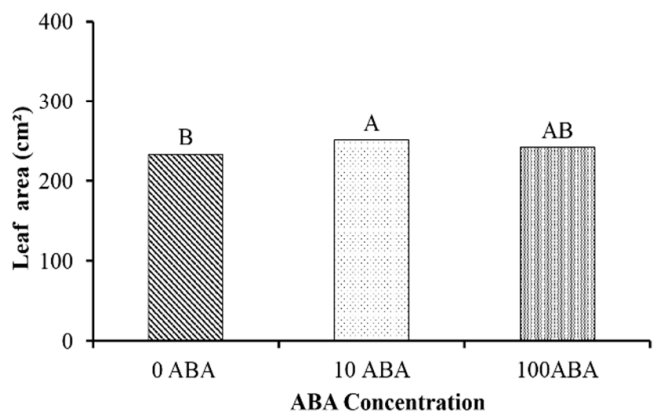

(B)

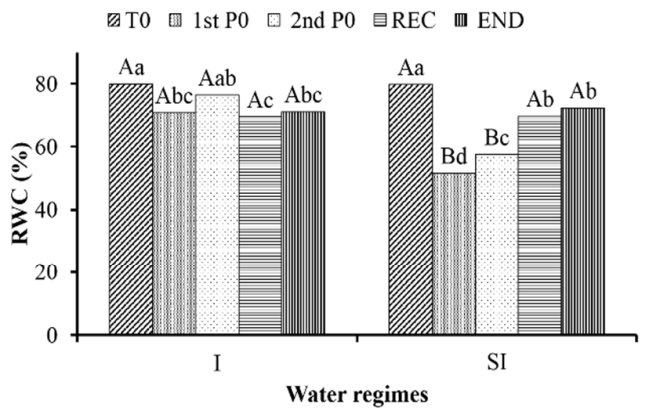

(D)

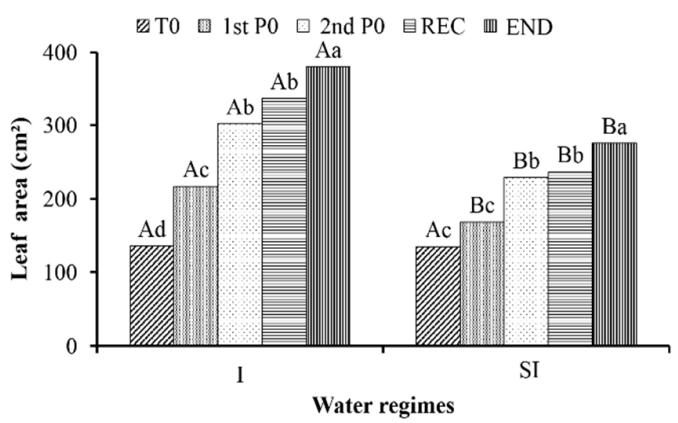

Figure 3. Relative water content (RWC) (A-B) and leaf area (C-D) of Calophyllum brasiliense subjected to different water regimes (irrigated-I and suspension of irrigation-SI), ABA concentrations $(0,10$ and 100 $\mu \mathrm{M}$ ) and evaluation times (time zero- $\mathrm{T}_{0}$, first and second photosynthesis near zero $-1^{\text {st }} \mathrm{P} 0$ and $2^{\text {nd }} \mathrm{P} 0$, recovery-REC and final evaluation END). Capital letters compare different water regimes in the same concentration of ABA (A) and evaluation period (B-D). Lowercase letters compare different concentrations of $\mathrm{ABA}(\mathrm{A})$ and evaluation periods $(\mathrm{B}-\mathrm{D})$ in the same water regimes. 
(A)

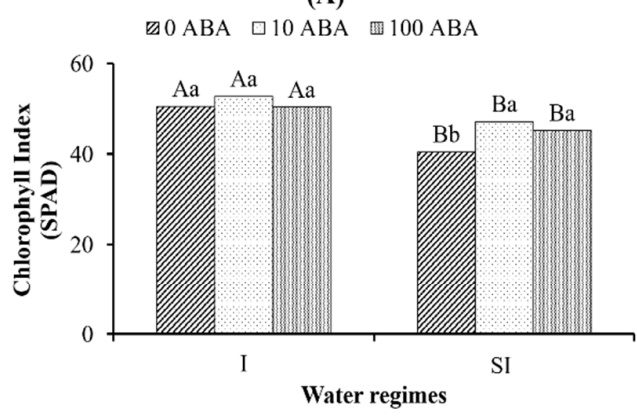

(C)

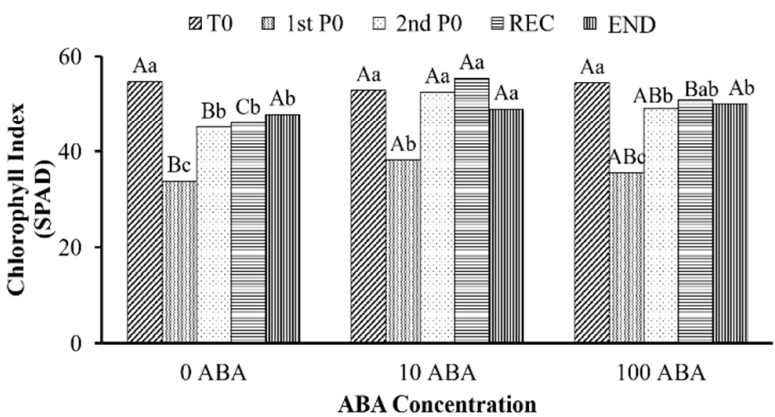

(B)

? 0 0 1st P0 $\square 2$ nd P0 目 REC III END

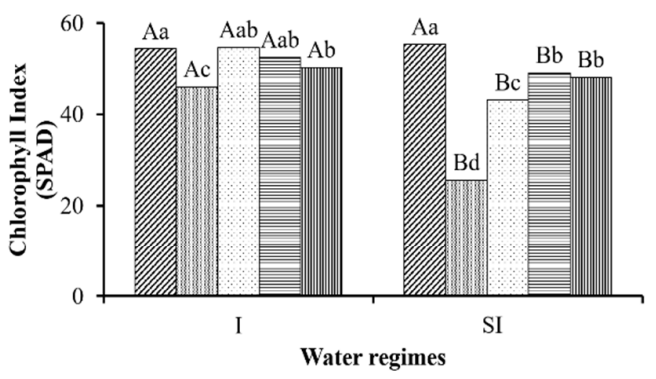

(D)

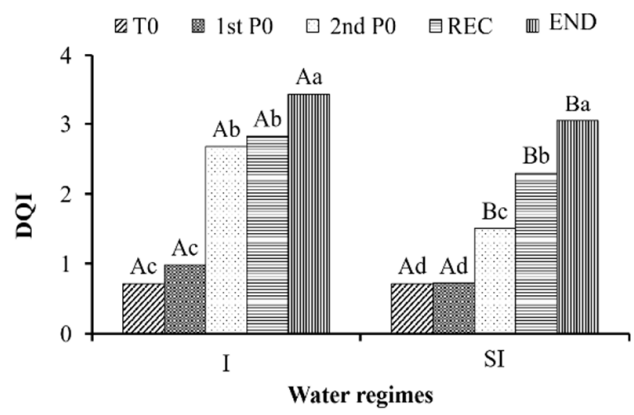

Figure 4. Chlorophyll index (SPAD)(A-B-C) and Dickson quality index (DQI) (D) seedlings of $C$. brasiliense subjected to different water regimes (irrigated-I and suspension of irrigation-SI), ABA concentrations $(0,10$ and $100 \mu \mathrm{M})$ and evaluation periods (time zero-T0, first and second photosynthesis near zero - $1^{\text {st }} \mathrm{P} 0$ and $2^{\text {nd }} \mathrm{P} 0$, recovery-REC and final evaluation END).Capital letters compare different water regimes $(\mathrm{A})$ and evaluation periods $(\mathrm{B}, \mathrm{D})$ in the same concentration of $\mathrm{ABA}$ and the same evaluation periods and the same evaluation times in different concentration of $A B A(C)$. Lowercase letters compare different concentrations of $\mathrm{ABA}(\mathrm{A})$ and evaluation periods $(\mathrm{B}, \mathrm{D})$ in the same water regimes and the same concentration of $\mathrm{ABA}$ in different evaluation periods $(\mathrm{C})$

\section{Discussion}

The intermittent water deficit reduces the water status of $C$. brasiliense, which impairs the functioning of the photochemical apparatus and the quality of the seedlings. After the reirrigation of the seedlings and until the end of the evaluations, most of the characteristics evaluated reached values close to that of the control seedlings, showing that the damage was not irreversible. However, for the quality of the seedlings and the leaf area, the period evaluated may not have been sufficient for the metabolic adjustment, which may have occurred after the second reirrigation, to reflect the growth and consequently the quality of the seedlings.

In plants, water deficit affects water potential, nutritional status, leaf gas exchange, the efficiency of capture, transfer and conversion of energy by photosystems, mechanisms and physiological processes related to growth (Rohácek, 2002; Zanandrea et al., 2006; Campelo et al., 2015; Rosa et al., 2017; Nunes et al., 2017; França et al., 2017).

Studies have provided reference values related to chlorophyll $a$ fluorescence, which has been used to predict stress condition. The reference values for the $F_{v} / F_{m}$ range between 0.750 and 0.850 (Baker and Rosenqvst, 2004). However, these values are subject to a range of variation that depends, on the species, its physiological mechanisms and growth (Li et al., 2004; Zanandrea et al., 2006). For the $\mathrm{F}_{\mathrm{v}} / \mathrm{F}_{0}$, the values that reflect the maintenance of good state of functionality of the PS II reaction centers are between 4 and 6; values 
below this range indicate stress. This characteristic can be used as an indicator of the maximum efficiency of the photochemical process in PSII and/or potential photosynthetic activity. Similarly, the reference for the $\mathrm{F}_{0} / \mathrm{F}_{\mathrm{m}}$ is between 0.14 and 0.20 , suggesting that the increase in this ratio is indicative of stress (Rohácek, 2002).

Thus, we can use these fluorescence characteristics as reliable parameters to evaluate the cultivation condition of C. brasiliense seedlings, which indicated the stress condition in the present study due to water deficit.This was reinforced by the changes in other characteristics evaluated, such as leaf area, chlorophyll index, and seedling quality.

Under water deficit condition, $C$. brasiliense seedlings presented a reduction in the $\mathrm{F}_{\mathrm{v}} / \mathrm{F}_{\mathrm{m}}$, which is similar to the findings ofother studies with different species under water stress, such as Hancornia speciosa (Scalon et al., 2015), Swietenia macrophylla King, C. brasiliense and Handroanthus albus (Cham.) Mattos (Campelo et al., 2015), Hymeneae coubaril L. (Freitas et al., 2018).

The higher $\mathrm{F}_{\mathrm{v}} / \mathrm{F}_{\mathrm{m}}$ reduction observed at the $1^{\mathrm{st}} \mathrm{P} 0$ period reinforces the stress condition of the nonirrigated C. brasiliense seedlings. However, after re-irrigation, the $\mathrm{F}_{\mathrm{v}} / \mathrm{F}_{\mathrm{m}}$ ratio was restored, and the $\mathrm{ABA}$ concentration in the END evaluation period was higher than 0.75 , indicating that there were no permanent damages to the photosynthetic apparatus.

The $\mathrm{F}_{\mathrm{v}} / \mathrm{F}_{0}$ ratio was also lower at the ${ }^{\mathrm{st}} \mathrm{P} 0$ evaluation period. However, at the REC and END evaluation periods, the seedlings presented values close to those of the control, indicating the efficiency of $C$. brasiliense seedlings in tolerating stress. The $\mathrm{F}_{0} / \mathrm{F}_{\mathrm{m}}$ ratio increased significantly in the $1^{\text {st }} \mathrm{P} 0$ period, and after re-irrigation, the tendency of reduction was observed. However, the values were maintained above the reference values and those of the control, except in the seedling treated with $10 \mu \mathrm{M} \mathrm{ABA}$.

Calophyllum brasiliense, S. macrophylla and $H$. albus showed higher sensitivity to water deficit than that of other species. This was reflected by higher reductions in gas exchange and the photochemical efficiency of PS II (Campelo et al., 2015). Freitas et al. (2018) working on H. coubaril with different concentrations of ABA, verified water stress attenuation, thus, a reduction in the functions of PS II.

The seedlings of $C$. brasiliense under water deficit condition presented reduced leaf area in relation to the plants irrigated from the $1^{\text {st }} \mathrm{P} 0$; although the leaf area increased at the end of the experiment, the seedlings under stress did not reach values close to those of the control plants (I).

Abscisic acid increased leaf area and did not cause leaf abscission in C. brasiliense seedlings. The ABA alters the growth and development of plants and regulates the adaptive responses under conditions of low water availability, such as opening and closure of the stomata, leaf abscission, and root growth (Zhu, 2002; Tardieu et al., 2010; Vieira et al., 2017). The leaf area of $C$. brasiliense seedlings treated with $10 \mu \mathrm{m} \mathrm{ABA}$ was higher than that of the seedlings not treated with ABA.

Furthermore, Tardieu et al. (2010) suggest that the positive effect of ABA on leaf expansion is attributed to the increase in the hydraulic conductivity of the root system at the same time as it leads to the stomatal closure and consequently to the maintenance of leaf turgescence.

In the present study, the plants under water deficit condition exhibited reduced leaf area at the $2^{\text {nd }} \mathrm{P} 0$ period. Although the leaf area of seedlings under stress increased, which can be attributed to the natural growth of the plant, it did not attain the control values. The reduction in the leaf area of woody plants as a response to low soil water availability has been proven in several species. Similar results were observed for Guazuma ulmifolia (Scalon et al., 2011) and Vatairea macrocarpa (Benth.) Ducke (Vieira et al., 2017).

The chlorophyll index varied according to the treatments, however, stressed seedlings treated with 10 $\mu \mathrm{M}$ ABA maintained higher SPAD index in relation to that of the seedlings subjected to other treatments under stress, observing also hormonal action between the evaluation periods. The $1^{\text {st }} \mathrm{P} 0$ was the time that presented the lowest chlorophyll index in all the treatments with or without ABA application. At the dose of $10 \mu \mathrm{M} \mathrm{ABA}$, the values were higher than that of the treatment without $\mathrm{ABA}$ at the $2^{\text {nd }} \mathrm{P} 0$ and REC periods. At the other periods of evaluation, there was an increase in the SPAD index; however, they did not attain the control values. 
Generally, plants under water stress present reduced photosynthetic pigment content due to oxidative damages, thus affecting photosynthesis (Asharaf and Harris, 2013) and consequently the production of dry mass and leaf area expansion, which reflected the reduction of DQI, to C. brasiliense seedlings.

Seedlings ofHymenaea coubaril treated with $10 \mu \mathrm{M}$ ABA both in the photosynthesis close to zero and in the recovery period, presented SPAD index close to that of the control seedlings. However, chlorophyll index values showed reduced for plants treated with $100 \mu \mathrm{M} A B A$, independent of water availability and the DQI did not differ significantly among the different treatments throughout the experimental period (Freitas et al., 2018).

Under water deficit condition, Schinus terebinthifolius showed reduced chlorophyll index (SPAD) when the seedlings reached almost zero photosynthesis $\left(1^{\text {st }} \mathrm{P} 0\right)$ and did not recover after irrigation (Nunes et al., 2017). Furthermore, Copaifera langsdorffii seedlings showed the lowest SPAD index at $25 \%$ and $100 \%$ FC (Rosa et al., 2017). Other species such as Khaya ivorensis, Calophyllum brasiliense, Astronium fraxinifolium, Handroanthus albus, and Simarouba amara also presented a reduction in chlorophyll content due to water deficit (Campelo - unpublished data).

Dickson quality index of $C$. brasiliense seedlings under water deficit condition at T0 and $1^{\text {st }} \mathrm{P} 0$ periods did not change significantly from that of the seedlings subjected to irrigation treatments. At the other evaluation periods, the seedlings under stress presented lower DQI, which might be due to lower biomass production for growth and target metabolism for defense mechanisms, such as increased enzyme activity (data not shown). Dickson Quality Index indicates robustness of seedlings; the higher the value, the better the quality (Moraes et al., 2012; Gordin et al., 2016).

Schinus terebinthifolius at different irrigation depths $(8,10,12$, and $14 \mathrm{~mm})$ also showed lower DQI when they received the lowest amount of water (Moraes et al., 2012). Similar results were observed in Hancornia speciosa seedlings when grown at $25 \%, 50 \%, 75 \%$ and $100 \%$ substrate water retention capacity, they presented lower DQI at 25\% and 50\% RWC (Gordin et al., 2016). As stressed seedlings, even after rehydration, did not attain quality indexes similar to those of control seedlings, we believe that the period might not have been sufficient for them to recover.

In natural habitat, $C$. brasiliense is found in phytophysiognomy that present hyper seasonality, that is, dry and rainy seasons throughout the year, causing oscillations in the soil water status (Souza et al., 2018), causing the species to grow plants subjected to the water deficit condition at certain periods. Under reduced soil water availability (dry season $-1^{\text {st }} \mathrm{P} 0$ and $2^{\text {nd }} \mathrm{P} 0$ ), C. brasiliense seedlings reduced the efficiency of activities in PSII, indicating stress conditions for maintenance of metabolic processes, as well as physiological plasticity by reversing photochemical damage, at the end of evaluation period.

The application of $\mathrm{ABA}$ in adequate amounts is a practice that substantially contributed to the mitigation of photochemical damage, maintaining the integrity of photosynthetic apparatus until the rainy season, characterized by re-irrigation, ensuring the development of seedlings and restoration of ecosystem services. Thus, study of plant photochemical responses to environmental variants contributes understanding of processes resulting from PSII under adverse conditions, aiming at the in situ and ex situ conservation.

\section{Conclusions}

The fluorescence measurements helped identify the stress condition of water deficit in the cultivation of $C$. brasiliense and the beneficial effect of the application of $10 \mu \mathrm{M} \mathrm{ABA}$ in minimizing stress and in facilitating the recovery of seedlings after re-irrigation, while, maintaining the integrity and function of the photosynthetic apparatus. 


\section{Acknowledgements}

The National Council for Scientific and Technological Development (CNPq) and Coordination for the Improvement of Higher Education Personnel (CAPES), for the granting of scholarships, and the Foundation for Support to the Development of Education, Science and Technology of the State of Mato Grosso do Sul (FUNDECT) for financial support.

\section{Conflict of Interests}

The authors declare that there are no conflicts of interest related to this article.

\section{References}

Asharaf M, Harris PJC (2013). Photosynthesis under stressful environments: an overview. Photosynthetica 51:163-190.

Baker NR, Rosenqvst E (2004). Applications of chlorophyll fluorescence can improve crop production strategies: an examination of future possibilities. Journal Experimental Botany 55:1607-1621.

Brodribb TJ, Mcadam AS (2001). Abscisic acid mediates a divergence in the drought response of two conifers. Plant Physiology 162:1370-1377.

Campelo DH, Lacerda CF, Sousa JA, Correia D, Bezerra AME, Araújo JDM, Neves ALR (2015). Leaf gas exchange and efficiency of photosystem II in adult plants of six forest species as function of the water supply in the soil (Title English). Revista Árvore 39:973-983.

Carvalho PER (2003). Espécies arbóreas brasileiras. Brasília, DF: Embrapa Informação Tecnologia; Colombo-PR: Embrapa Florestas, pp 103.

Damour G, Simonneau T, Cochard H, Urban L (2010). An overview of models of stomatal conductance at the leaf level. Plant Cell Environment 33:1419-1438.

Dickson A, Leaf AL, Hosner JF (1960). Quality appraisal of white spruce and white pine seedling stock in nurseries. Forest Chronicle 36:10-13.

Ferreira DF (2014). Sisvar: a guide for its Bootstrap procedures in multiple comparisons. Ciência e Agrotecnologia 38:109-112.

França PHT, Silva ECA, Silva TC. Brasil NA, Nogueira RJMC (2017). Physiological analysis in seedlings of guanandi (Calophyllum brasiliense Cambess.) under a water deficit (Title English). Agropecuária Científica no Semi-Árido 13:264-269.

Freitas VMB, Scalon SPQ, Dresch DM, Bastos SS, Souza APR (2018). Influence of exogenous application of abscisic acid on gas exchanges in Hymenaea courbaril L. (Fabaceae) seedlings subjected to water deficit. Floresta 48:163-172.

Gordin CRB, Marques RF, Scalon SPQ (2016). Emergence and initial growth of Hancornia speciosa (Gomes) seedlings with different substrates and water availability. Revista Ciências Agrárias 59:352-361.

Kalaji HM, Rastogi A, Živčák M, Brestic M, Daszkowska-Golec A, Sitko K, ... Cetner MD (2018). Prompt chlorophyll fluorescence as a tool for crop phenotyping: an example of barley landraces exposed to various abiotic stress factors. Photosynthetica 56:953-961.

Kalil Filho NA, Marzollo LG, Lopes AJ, Wendling I (2007). Produção de mudas de guanandi. Comunicado Técnico Embrapa, Colombo 177 pp 4,.

Kowitcharoen L, Wongs-Aree C, Setha S Komkhuntod R, Srilaong V, Kondo S (2015). Changes in abscisic acid and antioxidant activity in sugar apples under drought conditions. Scientia Horticulturae 193:1-6.

Li RH, Guo PG, Michael B, Stefania G, Salvatore C (2006). Evaluation of chlorophyll content and fluorescence parameters as indicators of drought tolerance in barley. Agricultural Sciences in China 5:751-757.

Mohammadi H, Janmohammadi M, Sabaghinia N (2015). Chlorophyll fluorescence response of wheat to exogenous application of growth regulators under terminal drought stress. Annales Universitatis Mariae Curie-Sklodowska 70:13-27.

Moraes WWC, Susin F, Vivian MA, Araújo MM (2012). Influence of the irrigation in the growth Schinus terebinthifolius seedlings (Title English). Pesquisa Florestal Brasileira 32:23-28. 
Reis LC et al. (2020). Not Bot Horti Agrobo 48(1):210-220.

220

Nesterenko TV, Shikhov VN, Tikhomirov AA (2019). Estimation of changes in the activity of photosynthetic apparatus of plant leaves based on half-time of fluorescence intensity decrease. Photosynthetica 57:132-136.

Nunes DP, Scalon SPQ, Dresch DM, Gordin CRB (2017). Photosynthetic and enzymatic metabolism of Schinus terebinthifolius Raddi seedlings under water deficit. Ciência e Agrotecnologia 41:676-682.

Rohácek K (2002). Chlorophyll fluorescence parameters: the definitions, photosynthetic meaning, and mutual relationships. Photosynthetica 40:13-29.

Rosa DBCJ, Scalon SPQ, Cremon T, Ceccon F, Dresch DM (2017). Gas exchange and antioxidant activity in seedlings of Copaifera langsdorffii Desf. under different water conditions. Annais da Academia Brasileira de Ciências 89:3039-3050.

Sarafraz-Ardakani MR, Khavari-Nejad RA, Moradi F, Najai F (2014). Abscisic acid and cytokinin-induced osmotic and antioxidant regulation in two drought-tolerant and drought-sensitive cultivars of wheat during grain filling under water deficit in yield conditions. Notulae Scientia Biologicae 6(3):354-362.

Scalon SPQ, Mussury RM, Euzébio VLM, Kodama FM, Kissmann C (2011). Water stress in metabolism and initial growth of mutambo (Guazuma ulmifolia Lam). Ciência Florestal 21:655-662.

Scalon SPQ, Kodama FM, Dresch DM, Mussury RM, Pereira ZV (2015). Gas exchange and photosynthetic activity in Hancornia speciosa Gomes seedlings under water deficit conditions and during rehydration. Bioscience Journal 31:11241132.

Souza AF, Rocha Junior EO, Laura VA (2018). Early development and efficiency in water and nitrogen use by seedlings of Calophyllum brasiliense, Eucalyptus urograndis, Tabebuia impetiginosa and Toona ciliata. Ciência Florestal 28:14651477.

Tardieu F, Parent B, Simonneau T (2010). Control of leaf growth by abscisic acid: hydraulic or non-hydraulic processes. Plant, Cell and Environment 33:636-647.

Vieira EA, Silva MG, Moro CF, Laura VA (2017). Physiological and biochemical changes attenuate the effects of drought on the Cerrado species Vatairea macrocarpa (Benth.) Ducke. Plant Physiology and Biochemistry 115:472-483.

Zanandrea I, Nassi FL, Turchetto AC, Braga EJB, Peters JA, Bacarin MA (2006). Effect of salinity under fluorescence parameters in Phaseolus vulgaris. Revista Brasileira de Agrociência 12:157-161.

Zhao WS, Sun YL, Kjelgren R, Liu X (2015). Response of stomatal density and bound gas exchange in leaves of maize to soil water deficit. Acta Physiologiae Plantarum 37:1704-1713.

Zhu JK (2002). Salt and drought stress signal transduction in plants. Annual Review of Plant Biology 53:247-273.

OPEN ACCESS

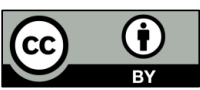

The journal offers free, immediate, and unrestricted access to peer-reviewed research and scholarly work. Users are allowed to read, download, copy, distribute, print, search, or link to the full texts of the articles, or use them for any other lawful purpose, without asking prior permission from the publisher or the author.

License - Papers published in Notulae Botanicae Horti Agrobotanici Cluj-Napoca are Open-Access, distributed under the terms and conditions of the Creative Commons Attribution (CC BY) License.

(c) Articles by the authors; UASVM, Cluj-Napoca, Romania. The journal allows the author(s) to hold the copyright/to retain publishing rights without restriction. 